TITLE:

\title{
Gromov-Witten class and A Perturbation Theory in Algebraic Geometry.(Abstract_要旨)
}

$\operatorname{AUTHOR}(S)$ :

Mochizuki, Takuro

\section{CITATION:}

Mochizuki, Takuro. Gromov-Witten class and A Perturbation Theory in Algebraic Geometry.. 京都大学, 1999, 博士 (理学)

ISSUE DATE:

1999-03-23

URL:

http://hdl.handle.net/2433/181933

RIGHT: 
氏名望望等拓郎

学位 (専攻分野) 博 士（理 学)

学位記番号理 博 第 2010 号

学位授与の日付平成 11 年 3 月 23 日

学位授与の要件 学位規則第 4 条第 1 項 該当

研究科. 専攻理学研究科数学. 数理解析専攻

学位論文題目 Gromov-Witten class and a Perturbation Theory in Algevraic Geometry.

(Gromov-Witten class と代数幾何における攝動の理論)

(主查)

論文調查委員教授河野 明教授西田吾郎 講師 清水勇二

論文内容の要旨

主論文における申請者望月拓郎氏の主たる研究テーマは現在代数幾何学や微分幾何学の分野で多くの研究者が興味を持ち 研究しているGromov Witten不変量の代数幾何学的構成であります。

$\mathrm{n}$ 点付き撞数 $\mathrm{g}$ のholomorphic curve，あるいはstable curveから複素代数多様体 $\mathrm{V} へ の$ morphismのmoduli spaceを考え ます。このときGromov Witten不変量とは大雑把に言うと，この空間をある意味で多様体と考えたときの良い基本木モ口 ジー類でいくつかの公理を満たす物として定式化することが出来ます。

この様な物を考えるのには次のような動機があります。

1. カラビーヤウ多様体上のrational curveの個数を与えるMirror conjecture

2. 量子コホモロジー代数の構成

3. Kontsevichによるenumerative geometryにおける古典的問題の解決

Gromov Witten不変量を構成する上では二つの困難がありました。まず第一の物は上のmoduli空間を何等かの意味でコ ンパクト化する必要があります。次の物はさらに大きな物でmoduliの次元が望ましい挙動を示さず幾何学的に不自然な物 になってしまうことです。この第二の困難を代数幾何学の枠内で解決することは極めて困難と考えられていましたし，たと え微分幾何学を用いるにしてもかなりの工夫が必要と思われていました。Kontsevichはmoduli stackで上のmoduliを含む properな物を考えコンパクト化の問題を解決しました。

Kontsevichは第二の点についても moduli stackがquasi-manifold structureを持つはずであり，これを用いて仮想の基本 ホモロジー類が構成できるという提案をしました。

主論文の中で申請者望月拓郎氏はこの問題を代数幾何学的に解決しました。

さらにKontsevichの研究やMirror conjectureへの応用で重要なこの構成をtotus作用に関して同変な物に拡張しさらにそ のBorel型の局所化定理の証明にも成功しております。

\section{論 文 審 査 の 結 果 の 要 旨}

主論文において，申請者望月拓郎氏はその主たる研究テーマで現在代数幾何学や微分幾何学の分野で多くの研究者が興味 を持ち研究しているGromov Witten不変量の代数幾何学的構成に成功しております。又参考論文でもKontsevichの仕事に 関連する重要な幾何学や微分方程式論に関する成果が得られています。

$\mathrm{n}$ 点付き撞数 $\mathrm{g}$ の holomorphic curve，あるいはstable curveから複素代数多様体 $\mathrm{V}$ のmorphismのmoduli spaceを考え ます。このときGromov Witten不変量とは大雑把に言うと，この空間をある意味で多様体と考えたときの良い基本ホモ口 ジー類でいくつかの公理を満をす物として定式化することが出来ます。 
Gromov Witten不変量を構成する上では二つの困難がありました。まず第一の物は基本ホモロジ一類を考えるためには 上のmoduli空間を何等かの意味でコンパクト化しなければなりません。次の物はさらに大きな物でmoduliの次元が望まし い挙動を示さずそのため境界の次元がもとの次元を越えるという幾何学的に不自然な物になってしまうことです。この第二 の困難を代数幾何学の枠内で解決することは極めて困難と考えられていましたし，たとえ微分幾何学を用いるにしてもかな りの土夫が必要と思われていました。

Kontsevichはmoduli stackで上のmoduliを含むproperな物を考えコンパクト化の問題を解決しました。

Kontsevichは第二の点についても moduli stackがquasi-manifold structureを持つはずであり，これを用いて仮想の基本 ホモロジー類が構成できるという提案をしました。

主論文の中で申請者望月拓郎氏はこの問題をこのKontsevichの構想を実現することで上にも述べたように多くの専門家 が困難と考えていた手法により代数幾何学的に解決しました。このためには多くの代数幾何学の最新の手法が用いられます。 さらにこの構成が極めて自然な物であることからKontsevichの研究やMirror conjectureへの応用で重要なこの構成をtotus 作用に関して同変な物に拡張することが可能になります。またそのBorel型の局所化定理の証明も比較的容易に出来ます。

以上のように望月拓郎氏の成果は最近の代数幾何学や微分幾何学の分野で多くの研究者が興味を持ち研究している Gromov Witten不変量の代数幾何学的構成を成し遂げた優れた物であり博士（理学）の学位論文として充分な物と考えま す。 